\title{
Developing Digital Competences of Vocational Teachers
}

\author{
Sabine Seufert \\ University of St. Gallen \\ Institute of Business Education and \\ Educational Management (IWP) \\ Dufourstrasse 40a \\ CH-900o St. Gallen \\ Sabine.Seufert@unisg.ch
}

\author{
Nina Scheffler* \\ University of St. Gallen \\ Institute of Business Education and \\ Educational Management (IWP) \\ Dufourstrasse 40a \\ CH-900o St. Gallen \\ Nina.Scheffler@unisg.ch
}

\begin{abstract}
In the context of corporate learning digital media and digital tools have become more accepted than in the field of education systems. Particularly vocational schools are obviously under pressure to deal with changes due to digitalization in many sectors and professions. One reason why technology-based learning is still underdeveloped in schools could be the insufficient digital competences of teachers. Presently most teachers gain their knowledge on how to use digital media for learning and teaching informally. In the implementation of formal educational efforts, a low practical feasibility in specific working context as well as time and financial aspects are criticized. Present research shows that non-formal and informal learning should be better linked in order to develop teachers' digital competences sustainably.

The present contribution introduces a necessary framework to include informal learning processes in teacher education at vocational schools and furthermore fosters a school culture of learning together and from each other.
\end{abstract}

Keywords: digital competences, teacher education, informal learning, professional communities, Selfinitiated learning, non-formal learning, media educational competences, school development. 


\section{Introduction: digital competences in vocational education}

Digital competences have become interdisciplinary and cross-generational cross-functional skills (Weiss, 2012), which employers usually already require of trainees and employees during and at the latest after their training. For this reason, there are growing calls to ensure sufficient media literacy for young people in the education sector. The aim of media education is to enable learning in schools with and through media and, through their integration in the curriculum and the development of technical and interdisciplinary skills, to contribute to constructively-oriented learning (Mayrberger, 2007, 2012). In addition, digital media provide ways to strengthen hands-on learning approaches in the classroom and integrate informal modes of learning into formal learning. In this sense, digital media perform a bridging function through their direct relevance to the students' lifestyles and serve "as a cultural resource enabling them to participate and become involved in social processes [...] and develop personal world views and their identity" (Herzig \& Grafe, 2009, p. 193, quoting Mayrberger, 2012, p. 401). The aim of media education is therefore to help individuals, in general and in a professional context, to use media knowledgeably, self-responsibly and critically (Seufert \& Scheffler, 2014) and shape training rooms as well as learning and educational processes independently based on digital media (Mayrberger 2012, p 403; Spanhel, 2009). In this context, (vocational) schools and teachers play a key role.

\section{Problem and Research Question}

Digital media have established themselves far more quickly and effectively in work and everyday life than in education (Weiss, 2012, p. 3). It is hoped that the use of media will improve learning efficiency, facilitate greater orientation to the future professional needs of learners and accompanied personality development in a digital society, etc. Digital media therefore are already part of vocational training at different levels: as part of the everyday life and work of students and teachers, as a method or as content in vocational school teaching. Especially the methodological and didactic use of digital media, often subsumed under the term eLearning, dominates public debate.Overall, however, the use of digital media and eLearning in vocational schools has only played a minor role to date (Wilbers, 2012, p. 38).

However, due to the growing importance in companies and thus the commercial part of the training, vocational schools are coming under increasing pressure to also address the implications of digital media for education and training. "In this area, vocational schools are facing a permanent and extremely differentiated need to adapt that is not seen in this scope or diversity in any other kind of school" (Wilbers 2012, p 40). Common teaching practices are seen as a central barrier to innovation. This is because whether or not media enter the classroom depends not only on the technical prerequisites, but also on the skills and the willingness of the individual teachers to try out new forms of teaching. So far, however, school routine is dominated by traditional forms of teaching, in which the tutorials, smaller individual and group work and lectures are predominant (Euler, 2012, p. 21). New teaching concepts, such as media-supported, problem-based learning or project forms featuring wikis or weblogs can only be integrated into such models to a limited extent.

Moreover, teachers addressing new digital skills such as the competent handling of online information are often entering uncharted territory in their respective fields (media education). In this context, teachers are increasingly demanding the teaching of media-specific qualification goals. However, what skills teachers need to acquire remains rather sketchy and is largely limited to the use and operation of the ICT (Blömeke, 2005). Furthermore, it is obvious that formal seminars, such as one-day training workshops in how to use ICT, are not sufficient and 
effective to develop teachers' digital competences. In order to be able to plan and design suitable education training measures for teachers initially requires a systematic approach for the professional development of teachers at vocational schools. The main research question of this paper focuses on this critical issue:

How to design a systematic approach for digital competences development (rather than the planning of selective training measures) from the perspective of both teachers and the school management?

In order to pursue the leading research question, the following questions structure the acquisition of knowledge:

- What skills do teachers in schools require when using digital media?

- What fundamental approaches to organising the skills development of teachers exist when dealing with digital media?

- How can formal and informal learning approaches be interlinked to facilitate the competence development of teachers in vocational schools, in particular in order also to promote the self-organisation of teachers?

The next section explains the applied research methodology; the fourth section provides an overview of the findings: 1) the required skill-set for teachers in digital times 2) general approaches to define and pursue digital competence frameworks and 3) forms of competence development by combining informal and formal learning (emerging alternatives to the dominant "training model" of teachers' professional development); and the last section concludes the paper by discussing the results and providing recommendations for future research.

\section{Research Methodology}

The main goal of the research presented in the paper at hand is to develop a conceptual framework for teachers' professional development focused on digital competencies in vocational schools. In order to achieve this goal a two-year research project has been established in cooperation with a secondary school in the German speaking part of Switzerland. The project is based on a methodological combination of literature analysis, model development and empirical model testing with focus on information literacy (IL) as part of digital competencies:

1. To get an overview of existing IL research a systematical literature analysis has been performed by focusing on the following research questions: Which terms exist associated with IL and how is IL defined in the literature? Which are the salient conceptualizations and measurement models of IL? Which methods are applied in order to examine IL?

2. Based on the findings of the literature research, and by combining and extending existing models, the 7i Framework for measuring IL has been created.

3. The 7i Framework for measuring IL has been tested in five classes at a Swiss secondary school involving 10 teachers.

The results of the literature analysis and model development are presented in detail in Stanoevska et al. (2015a) and Stanoevska et al. (2015b). A parallel research stream connected to the project was devoted to the analysis, design and evaluation of the necessary skills development of the involved teachers following a method mix:

1. Further literature analysis has been conducted in the field of teacher education with focus on digital competences. One main model to develop digital media skills of teachers represents the TPACK model developed by Koehler and Mishara (2009). This model offers a framework to further specify the required skills to integrate IL in teaching practice.

2. The teachers have been involved as practitioners in the design research process by sharing their knowledge and expertise from a subject-specific perspective. 
3. At the end of the project, an intensive focus group discussion has gained more insights in the question on what are necessary skills and support offerings for teachers to develop and permanently update their digital skills.

In summary, empirical practice reflection within the mentioned research project as well as a profound literature analysis provide the main research methods for the design of teachers' professional development.

\section{Results}

\subsection{Vocational teachers in the digital world: competence requirements and dimensions}

Teachers are increasingly demanding the teaching of media-specific qualification goals. However, what skills teachers need to acquire remains rather sketchy and is largely limited to the use and operation of the ICT (Blömeke, 2005, p. 76). In order to be able to plan and design suitable media education training measures for teachers initially requires a concrete discussion and formulation of the required skills (Petko \& Döbeli Honegger, 2011, p. 157).

According to Blömeke (2005), media education skills encompass two core tasks, derived from the basic tasks of "teaching" and "educating": the use of media or media didactics (learning with media) and media education (learning about media). When performing media education tasks, it is necessary to take into account both the media-specific requirements of the learners on the one hand and, on the other hand, the respective school environment, infrastructure and support structures. In summary, five dimensions of media education skills can be deduced (Blömeke 2005, p 77-79).

\section{Media teaching competences}

Teachers are able to address the subject of media in the classroom and can teach the learners to approach the subject of media critically.

2. Media pedagogy competences

Teachers are able to meaningfully use media as a method in terms of content and objectives and support teaching and learning processes with the aid of media.

\section{Socialisation-related competences in the media context}

Teachers take into account the media-specific learning requirements of the learners when preparing the lessons, are able to identify learning progress and can adequately assess and evaluate this. This includes understanding the media learning and living environments of the learners.

\section{Teacher's own media competences}

Teachers are able to competently use and actively shape media for themselves. The teacher's own media skills form the basis for all subsequent tasks.

5. School development competences in the media context

Teachers are able to help shape and develop the institutional framework for media education and advise students and parents on media education issues.

The first core task describes the ability to "use media in appropriate teaching-learning forms in a circumspect way" - in other words the ability to shape lessons using media. Vocational training serves as link between theory and practice. Therefore, it seems to be relevant to link a digital medial practice with a significant vocational content. Media teaching skills, as one of the core areas of media education competences (Blömeke, 2005, p. 91) thus builds on the experiences of the learners and teachers with digital media in the context of the living, learning 
and working environments. The understanding of media didactics illustrated here is supplemented by Mayrberger (2012) by a further aspect, namely "the delimitation of formal teaching and learning processes using digital media". Following Blömeke (2000), a person skilled in media didactics is, according to Mayrberger (2012), capable of using (digital) media in the classroom to create and reflect on student-centred learning environments, exploiting their specific potential to the full, and to critically assess the impact of integrating digital media on the formal and informal learning, and address the delimitation" (Mayrberger 2012, p 405).

The following table illustrates how learning processes in school-based vocational training can be supported using digital media and Web 2.0 applications.

Table 1. Learning with digital media in vocational training. (Adapted from: Seufert, 2012, p. 37).

\begin{tabular}{|c|c|c|c|}
\hline $\begin{array}{l}\text { Areas of vocational } \\
\text { training }\end{array}$ & $\begin{array}{l}\text { Pedagogical } \\
\text { perspective }\end{array}$ & Examples & $\begin{array}{l}\text { Exemplary facets of } \\
\text { a Web-application }\end{array}$ \\
\hline \multicolumn{4}{|c|}{ Media experiences of students and teachers } \\
\hline $\begin{array}{l}\text { Digital media as a } \\
\text { part of students' liv- } \\
\text { ing environments }\end{array}$ & $\begin{array}{l}\text { Dealing with media } \\
\text { mainly takes place in } \\
\text { informal contexts (In } \\
\text { interaction with peers) }\end{array}$ & $\begin{array}{l}\text { Computer gambling ad- } \\
\text { diction, smartphone, } \\
\text { classroom disturbances }\end{array}$ & $\begin{array}{l}\text { Facebook (Cyber- } \\
\text { mobbing, teacher as a } \\
\text { "friend")? }\end{array}$ \\
\hline $\begin{array}{l}\text { Digital media as a } \\
\text { part of teachers' } \\
\text { working and living } \\
\text { environments }\end{array}$ & $\begin{array}{l}\text { Dealing with media } \\
\text { usually informally }\end{array}$ & $\begin{array}{l}\text { Media use for prepara- } \\
\text { tion of classes }\end{array}$ & $\begin{array}{l}\text { Yammer as a commu- } \\
\text { nity platform }\end{array}$ \\
\hline \multicolumn{4}{|c|}{ Digital media as a method of teaching and learning in classes } \\
\hline $\begin{array}{l}\text { Enrichment of clas- } \\
\text { ses through integrat- } \\
\text { ing forms of e-learn- } \\
\text { ing }\end{array}$ & $\begin{array}{l}\text { Integration of media } \\
\text { elements as a teaching } \\
\text { / learning method in } \\
\text { classes }\end{array}$ & $\begin{array}{l}\text { Electronic text books, } \\
\text { e-Exams, educational } \\
\text { videos }\end{array}$ & $\begin{array}{l}\text { Open Resource educa- } \\
\text { tional videos (such as } \\
\text { "Explainity") }\end{array}$ \\
\hline $\begin{array}{l}\text { Using Learning } \\
\text { Management Sys- } \\
\text { tems (LMS) }\end{array}$ & $\begin{array}{l}\text { Using digital media as } \\
\text { an opportunity for } \\
\text { communication in } \\
\text { class }\end{array}$ & $\begin{array}{l}\text { Placing learning tasks, } \\
\text { communication across } \\
\text { learning places }\end{array}$ & $\begin{array}{l}\text { Facebook as a learn- } \\
\text { ing platform }\end{array}$ \\
\hline $\begin{array}{l}\text { Pedagogical „rede- } \\
\text { sign“ of courses in } \\
\text { general }\end{array}$ & $\begin{array}{l}\text { Designing media- } \\
\text { based educational } \\
\text { courses }\end{array}$ & $\begin{array}{l}\text { Information-based prob- } \\
\text { lem solving, } \\
\text { project-based learning } \\
\text { forms }\end{array}$ & $\begin{array}{l}\text { Preparation of a wiki } \\
\text { as joint project work, } \\
\text { Blogs as an reflection } \\
\text { tool }\end{array}$ \\
\hline \multicolumn{4}{|c|}{ Digital media as content, intentions and methods in classes } \\
\hline $\begin{array}{l}\text { Development of me- } \\
\text { dia literacy }\end{array}$ & $\begin{array}{l}\text { Critical and reflected } \\
\text { use of digital media }\end{array}$ & $\begin{array}{l}\text { Information literacy: } \\
\text { dealing with internet re- } \\
\text { sources, Net-Guidance- } \\
\text { measures }\end{array}$ & $\begin{array}{l}\text { Facebook: how to stay } \\
\text { safe online }\end{array}$ \\
\hline $\begin{array}{l}\text { Training how to use } \\
\text { digital media in pro- } \\
\text { fession }\end{array}$ & $\begin{array}{l}\text { Active and creative } \\
\text { design of digital me- } \\
\text { dia, } \\
\text { assessing and ques- } \\
\text { tioning media devel- } \\
\text { opments and trends } \\
\text { critically }\end{array}$ & $\begin{array}{l}\text { Using application soft- } \\
\text { ware for professional } \\
\text { specific tasks, } \\
\text { reflection changes in the } \\
\text { world of work by digital- } \\
\text { ization critically }\end{array}$ & $\begin{array}{l}\text { Social Media plat- } \\
\text { forms as a marketing } \\
\text { tool }\end{array}$ \\
\hline $\begin{array}{l}\text { Training experts } \\
\text { within the field of } \\
\text { digital media }\end{array}$ & $\begin{array}{l}\text { Professional compe- } \\
\text { tences: creating digital } \\
\text { realities and produc- } \\
\text { tive activity }\end{array}$ & $\begin{array}{l}\text { Programming languages, } \\
\text { ARIS-process-modelling }\end{array}$ & $\begin{array}{l}\text { Facebook Develop- } \\
\text { ment, e.g. API, De- } \\
\text { bugging }\end{array}$ \\
\hline
\end{tabular}




\begin{tabular}{|l|l|l|l|}
\hline $\begin{array}{l}\text { Framework for com- } \\
\text { petent use of digital } \\
\text { media }\end{array}$ & $\begin{array}{l}\text { Teachers design and } \\
\text { develop institutional } \\
\text { frameworks for work- } \\
\text { ing with digital media } \\
\text { in the fields of educa- } \\
\text { tion }\end{array}$ & $\begin{array}{l}\text { Developing curricular } \\
\text { modules to integrate in- } \\
\text { formation literacy: active } \\
\text { exchanges between } \\
\text { teachers }\end{array}$ & $\begin{array}{l}\text { collection of examples } \\
\text { for use blogs as re- } \\
\text { flection method and } \\
\text { tool }\end{array}$ \\
\hline $\begin{array}{l}\text { Consulting relevant } \\
\text { Stakeholders }\end{array}$ & $\begin{array}{l}\text { Advise students, par- } \\
\text { ents and teaching op- } \\
\text { erations in media ped- } \\
\text { agogical terms }\end{array}$ & $\begin{array}{l}\text { „Netiquette" or the } \\
\text { guidelines in use of So- } \\
\text { cial Media, development } \\
\text { of "digital self-compe- } \\
\text { tence" }\end{array}$ & $\begin{array}{l}\text { Social Media guide- } \\
\text { lines to coordinate ef- } \\
\text { ficiently among learn- } \\
\text { ing places }\end{array}$ \\
\hline
\end{tabular}

\subsection{Generic approaches to developing digital competences of teachers}

Schools face the challenge of how to organise the permanent upskilling of teachers in the use of digital media. Basically, there are two ideal approaches: subject-based approach vs. actionbased approach or product- vs. process-oriented curriculum models.

\section{Subject-based approach or product-oriented curriculum models}

Using this system, learning offers are structured according to subject-specific or thematic structures. Thus, "technology courses" are often offered in schools to train teachers in the use of new learning platforms or tablet PCs.

In terms of the promotion of media didactic skills of teachers, one example of a product-oriented model is the TPACK model developed by Koehler and Mishara (2009). The model offers a framework for concretising a required knowledge base for teachers for using technologies meaningfully for teaching and learning. Based on the observations in Shulman's pedagogical content knowledge (PCK) model (Shulman, 1986, 1987), the authors assume that the development of both technological pedagogical knowledge (TPK) and technological content knowledge (TCK) (together TPACK) is a prerequisite for successful technology-based teaching. The knowledge base (content, pedagogy and technology) form the core of the "technological, pedagogical and content knowledge" (TPACK), whereby the focus is particularly on the interaction and interfaces between the areas. The authors extend Shulman's model by the requisite technological knowledge and defined altogether the following seven Knowledge Areas (Table 2):

Table 2. TPACK Model - Knowledge Area, Guiding Questions, Mastery and Limitations.

\begin{tabular}{|c|l|l|l|}
\hline Knowledge Area & \multicolumn{1}{|c|}{ Description } & \multicolumn{1}{c|}{ Guiding Questions } & $\begin{array}{c}\text { Mastery and Limita- } \\
\text { tions }\end{array}$ \\
\hline $\begin{array}{c}\text { Content } \\
\text { Knowledge (CK) }\end{array}$ & $\begin{array}{l}\text { Knowledge about the teach- } \\
\text { ing subject and topic (theo- } \\
\text { ries, concepts, ideas etc.) of } \\
\text { the respective subject area. }\end{array}$ & $\begin{array}{l}\text { What content is rele- } \\
\text { vant to understand the } \\
\text { topic and should be } \\
\text { treated in this lesson? }\end{array}$ & $\begin{array}{l}\text { Master of the content } \\
\text { in the specific subject } \\
\text { area to reach a high } \\
\text { level of quality. }\end{array}$ \\
\hline $\begin{array}{c}\text { Pedagogical } \\
\text { Knowledge (PK) }\end{array}$ & $\begin{array}{l}\text { Knowledge about processes } \\
\text { and methods of learning } \\
\text { and teaching as pedagogical } \\
\text { principles and indicative } \\
\text { targets. This means an un- } \\
\text { derstanding about processes } \\
\text { how students gaining new }\end{array}$ & $\begin{array}{l}\text { What kind of pedagog- } \\
\text { ical principles should } \\
\text { be used in this lesson? }\end{array}$ & $\begin{array}{l}\text { Master of classroom } \\
\text { strategies, } \\
\text { use of learning theo- } \\
\text { ries, } \\
\text { different types of } \\
\text { methods, } \\
\text { evaluation methods. }\end{array}$ \\
\hline
\end{tabular}




\begin{tabular}{|c|c|c|c|}
\hline & $\begin{array}{l}\text { insights or how they could } \\
\text { be stimulated or motivated. }\end{array}$ & & \\
\hline $\begin{array}{l}\text { Technological } \\
\text { Knowledge (TK) }\end{array}$ & $\begin{array}{l}\text { Knowledge, which is more } \\
\text { than a pure application } \\
\text { knowledge. Rather it means } \\
\text { a broad understanding of } \\
\text { possibilities for technology- } \\
\text { based communication, in- } \\
\text { formation processing and } \\
\text { problem solving. }\end{array}$ & $\begin{array}{l}\text { Which technologies } \\
\text { should be used in this } \\
\text { lesson? }\end{array}$ & $\begin{array}{l}\text { Master of different } \\
\text { kind of technologies } \\
\text { and capable to provide } \\
\text { use technologies for } \\
\text { learning processes. }\end{array}$ \\
\hline $\begin{array}{l}\text { Technological } \\
\text { Content } \\
\text { Knowledge } \\
\text { (TCK) }\end{array}$ & $\begin{array}{l}\text { Knowledge about the way } \\
\text { how technologies and con- } \\
\text { tent interact which each } \\
\text { other. Furthermore teacher } \\
\text { need to know which spe- } \\
\text { cific tool is the most } \\
\text { adapted to convey the con- } \\
\text { tent or otherwise how the } \\
\text { content determined a useful } \\
\text { technology. }\end{array}$ & $\begin{array}{l}\text { Does the use of tech- } \\
\text { nologies will support } \\
\text { representing the con- } \\
\text { tent on multiple ways } \\
\text { or will they help for a } \\
\text { better understanding? }\end{array}$ & $\begin{array}{l}\text { Use technologies to } \\
\text { enhance the under- } \\
\text { standing of content but } \\
\text { neglected learning the- } \\
\text { ories. So it is modern } \\
\text { but limited. }\end{array}$ \\
\hline $\begin{array}{l}\text { Pedagogical Con- } \\
\text { tent Knowledge } \\
\text { (PCK) }\end{array}$ & $\begin{array}{l}\text { Knowledge about different } \\
\text { opportunities to teach a } \\
\text { specific content and with } \\
\text { taking into account the stu- } \\
\text { dents' prior knowledge, ed- } \\
\text { ucation guidelines on cur- } \\
\text { ricula and requirements. }\end{array}$ & $\begin{array}{l}\text { Does the underlying } \\
\text { pedagogical principles } \\
\text { foster the understand- } \\
\text { ing of the topic or } \\
\text { stimulate a deeper } \\
\text { learning? }\end{array}$ & $\begin{array}{l}\text { A } 20^{\text {th }} \text { Century class- } \\
\text { room with strong con- } \\
\text { tent and well imple- } \\
\text { mentation of pedagog- } \\
\text { ical theories. But in the } \\
21^{\text {th }} \text { Century it is obso- } \\
\text { lete because of neglect } \\
\text { technologies. }\end{array}$ \\
\hline $\begin{array}{l}\text { Technological } \\
\text { Pedagogical } \\
\text { Knowledge } \\
\text { (TPK) }\end{array}$ & $\begin{array}{l}\text { Knowledge how teaching } \\
\text { and learning could change } \\
\text { and influence each other. It } \\
\text { needs an understanding } \\
\text { about the restrictions and } \\
\text { affordance of technologies } \\
\text { as well as the resulting ped- } \\
\text { agogic-didactic conse- } \\
\text { quences within a discipli- } \\
\text { nary context. }\end{array}$ & $\begin{array}{l}\text { Are the pedagogical } \\
\text { principles and selected } \\
\text { technologies well } \\
\text { matched? }\end{array}$ & $\begin{array}{l}\text { Focused using technol- } \\
\text { ogies for learning and } \\
\text { helps learners to use it } \\
\text { in different ways. But } \\
\text { the learning activities } \\
\text { could take them away } \\
\text { from the actual learn- } \\
\text { ing content. }\end{array}$ \\
\hline $\begin{array}{l}\text { Technology, Ped- } \\
\text { agogy, and Con- } \\
\text { tent Knowledge } \\
\text { (TPACK) }\end{array}$ & $\begin{array}{l}\text { Knowledge of the interac- } \\
\text { tion and interfaces of con- } \\
\text { tent, technology and peda- } \\
\text { gogy in terms of the spe- } \\
\text { cific context (like previous } \\
\text { knowledge or legal and } \\
\text { technological conditions). It } \\
\text { needs an understanding in } \\
\text { how these domains and } \\
\text { contextual parameters inter- } \\
\text { faces. }\end{array}$ & $\begin{array}{l}\text { Does the selected tech- } \\
\text { nologies foster the un- } \\
\text { derlying pedagogical } \\
\text { principles and can the } \\
\text { interaction of both } \\
\text { contribute to a better } \\
\text { understanding of the } \\
\text { content? }\end{array}$ & $\begin{array}{l}\text { A masterful } 21^{\text {th }} \text { Cen- } \\
\text { tury classroom, which } \\
\text { considered the learn- } \\
\text { ing contents, based on } \\
\text { good learning theories } \\
\text { provide by technolo- } \\
\text { gies. }\end{array}$ \\
\hline
\end{tabular}

In so doing it becomes clear how complex the model is to apply in practice. The relevant context varies depending on the teacher, students, technological conditions, subject, content, and 
the teacher's understanding of teaching and requires a constant readjustment of teaching concepts. As already mentioned, this is generally the case but is further enhanced by the use of technologies. It is not possible to derive generally-valid standard solutions for teaching with technology as a subject of further training. Rather, skills are required that allow teachers to solve everyday problem situations flexibly and appropriate to the situation and to promote an understanding of teaching with technology. "There is no 'one best way' to integrate technology into curriculum. [...] Teaching successfully with technology requires continually creating, maintaining, and re-establishing a dynamic equilibrium among all components. [...] This is the kind of deep, flexible, pragmatic, and nuanced understanding of teaching with technology we involved in considering TPACK as a professional knowledge construct" (Koehler \& Mishara, 2009, p. 67).

Based on the defined areas of knowledge of the TPACK model, the corresponding educational goals can be derived for describing a skills profile. The respective knowledge must be put in an application-specific context. The advantage of such an approach lies in the exact definition of the necessary knowledge base, the necessary skills and attitudes. This enables overlaps in the basic knowledge base to be avoided. The disadvantages include in particular the fact that teachers may not be able to derive any practical relevance for their lessons. Thus, for example, courses are often not geared towards the integration of technical knowledge in specific teaching situations, which therefore makes it difficult for teachers to apply a hands-on approach.

\section{Action-based approach or process-oriented curriculum models}

While product models are structured according to a substantive, subject-based structure, process-specific models favour an action-based approach. Process-oriented curriculum models are process-oriented and geared towards accomplishing a process, in the sense of complete action. A process-based model emphasises especially learning from work and life experience and aims to enable learners to independently cope with professional situations. Here, learning objectives are open and contents relate more to empirical knowledge and knowledge that is to be newly generated in the specific situations (Sloane, 2002, p. 9). Based on a process curriculum, requirements, objectives, content and skills development measures are recorded and derived from reconstructed areas of activity - from the situations encountered by the learners in their living environments.

Euler, Hasanbegovic, Kerres, \& Seufert (2006) illustrate an example of such an action-based approach in their evaluation report for the determination of measures for the development of e-training skills for lecturers. Following Kerres, Euler, Seufert, Hasanbegovic, \& Voss (2005), a competence analysis was performed for ten exemplary e-learning scenarios and the requirements determined arranged in a skills/competence grid as an analytical tool (TARGET state). The CURRENT state was determined by means of questionnaires and interviews. The difference between the CURRENT and TARGET state served as the basis for deriving suitable skills development measures (see illustration below).

Table 3. Competence requirements derived from technology-based learning (Adapted from Euler et al. 2006).

\begin{tabular}{|c|c|c|}
\hline Use of media & Technology-based Learning & Required competences \\
\hline \multirow{2}{*}{$\begin{array}{l}\text { Digital media } \\
\ldots \text { in } \\
\text {,in-class training“ }\end{array}$} & $\begin{array}{ll}1 & \text { Teacher-centered lessons with } \\
\text { use of media }\end{array}$ & \multirow{2}{*}{$\begin{array}{l}\text { For the presented scenarios, } \\
\text { competences are specified for } \\
\text { the following action areas: }\end{array}$} \\
\hline & $\begin{array}{l}\text { Cooperative learning with digi- } \\
\text { tal learning resources and tools }\end{array}$ & \\
\hline
\end{tabular}




\begin{tabular}{|c|c|c|c|}
\hline & & $\begin{array}{l}\text { Testing of learning success } \\
\text { with e-assessment }\end{array}$ & $\begin{array}{l}\text { - Professional competences } \\
\text { - Social competences }\end{array}$ \\
\hline \multirow{4}{*}{$\begin{array}{l}\ldots \text { as a supplement to } \\
\text { „in-class training““ } \\
\ldots \text { as a significant ex- } \\
\text { tension to „in-class } \\
\text { training“ }\end{array}$} & & $\begin{array}{l}\text { Self-regulated learning by e-tu- } \\
\text { toring }\end{array}$ & - Self-competences \\
\hline & 5 & $\begin{array}{l}\text { Reflective learning in discus- } \\
\text { sion forums }\end{array}$ & \multirow{6}{*}{$\begin{array}{l}\text { And for activities: } \\
\text { - Knowledge } \\
\text { - Skills } \\
\text { - Attitudes }\end{array}$} \\
\hline & 6 & $\begin{array}{l}\text { case-based learning with web } \\
\text { resources }\end{array}$ & \\
\hline & 7 & $\begin{array}{l}\text { Discovery learning with com- } \\
\text { puter-based simulations }\end{array}$ & \\
\hline \multirow{3}{*}{$\begin{array}{l}\ldots \text { as a replacement } \\
\text { for } \\
\text {,in-class training“ }\end{array}$} & 8 & $\begin{array}{l}\text { project-oriented learning with } \\
\text { digital media }\end{array}$ & \\
\hline & & $\begin{array}{l}\text { Online learning with video } \\
\text { conferencing system }\end{array}$ & \\
\hline & 10 & $\begin{array}{l}\text { Dialogue-based learning with } \\
\text { virtual classroom }\end{array}$ & \\
\hline
\end{tabular}

In the first column of the table above, three possible areas categorise the use of digital media. Within these areas, it is possible to deduce specific learning scenarios and required competences. In the process-based or action-based approach, application situations are defined at the outset, to which the content to be taught, the required knowledge or the skills to be developed etc. must be assigned.

The aim is to create a comprehensive media education skillset and to enable teachers to apply and address digital media meaningfully and appropriately in the classroom in different situational contexts. Knowledge itself is only the basis for successfully doing so (Euler \& Hahn, 2004, 2014; Euler et al., 2006). That is to say, teachers need a complex system of knowledge (know what), skills (know how) and attitudes (know why) to be able to successfully employ digital media in teaching. In addition to the knowledge and skills required by the teachers and organisational support structures, the extent to which technologies will be able to establish themselves in learning and in the classroom depends fundamentally on a positive basic attitude on the part of the teachers (Petko \& Döbeli Honegger, 2011, p. 157). Therefore, the attitudes and beliefs of the teachers play an equally important role. Although Koehler \& Mishara (2009, p. 61) point out: "Moreover, this knowledge is unlikely to be used unless teachers can conceive of technology uses are consistent with their existing pedagogical beliefs," a corresponding skills development is not apparent in their model. In an action-based approach, the necessary attitudes are explicitly highlighted.

In addition to product- and process-oriented models, curricula can be developed on the basis of more flexible models that can be understood as a further form of an action-based model. In this context, informal learning opportunities are especially important. This aspect will be discussed in more detail below.

\subsection{Forms of competence development: combining informal and formal learning}

Common teacher training practices are in themselves a major barrier to why the digital media teaching skills of teachers are only developing to a limited extent. Like their students, most teachers learn how to use digital media less in formal learning situations, but rather informally in practice.Teachers often simply lack the time to attend a course or to work on a self-learning programme every time (Weiss, 2012, p. 3). As numerous studies show, teachers generally seem to develop their skills predominantly informally in the context of their teaching practice, 
in exchange with colleagues and through critical, individual reflection (Hoekstra, Korthagen, Brekelmans, Beijaard, \& Immants, 2009; Meirink, Meijer, Verloop, \& Bergen, 2009) Learning in informal contexts takes place alone or with others outside of institutionalised teaching environments. In contrast, learning under formal conditions takes place in training and further education institutions where professional teachers endeavour to learn how to teach, assess and if necessary even to certify. At voluntary further education events for teachers the fact that the individuals who generally attend usually already have a certain level of expertise is often criticised and they often return to school disappointed because what they learn is difficult to put into practice for lack of time and money. In addition, school-based training courses (SBT) that are tailored to the needs of a school are very widespread. However, some research studies show that even here formally organised school-based events also have a limited impact (Jurasaite-Harbison, 2009; Richardson, 2003). Therefore, the international research literature on the education and training of teachers increasingly focuses on workplace-integrated learning, which takes informal learning into account more (Hoekstra et al., 2009; Zwart, Wubbels, Bolhuis, \& Bergen, 2008), One key finding is that formal and informal learning should be more closely interlinked for the skills development of teachers. A promising approach would in particular appear to be the search for interfaces between learning in formal and informal contexts (Engestrøm, 2004).

The following section focuses on the importance of the skills development of teachers in this context. Heise (2007) particularly emphasises the importance of largely self-directed further education in this professional field. To support and strengthen these desired informal learning activities, it would appear absolutely essential to create an environment conducive to communication within the school organisation. The targeted encouragement of professional discussions before classes begin or during breaks and the use of free periods for detailed reflection, for example on critical practical situations, can make an important contribution to triggering and promoting informal learning among teaching staff (Heise, 2009). However, not all teachers will be willing or able to collaborate with their colleagues on the preparation and followup of the classes. On the contrary, a certain proportion of teachers usually work alone, which might make a different kind of support necessary than would be required for teachers that already cooperate or collaborate with one another (Hoekstra et al., 2009). A concept to promote informal learning tailored individually to the aims and objectives of teachers could therefore generate added value for curriculum and school development.

In the field of media literacy, for example, the pressure on teachers to seek further education has increased immensely due to the constant and rapidly advancing technological development.

Skills transfer. How might skills development measures for teachers which integrate learning in informal contexts be structured in practice? As explained above, "standardized" training programs have little impact on teacher education. In order to change teaching practice alternative training formats should be integrated into the portfolio. Some examples are outlined below (see following illustration):

Insert Figure 1 here

Transfer-oriented training. School-based training (SBT) is basically nothing new. However, it is now often combined more than was the case in the past with measures that support the transfer of what has been learned (such as preparatory phases and follow-ups). Effective results can for example also be achieved with more open learning environments, such as 
Engestrøm's Change Laboratory ${ }^{\circledR}(2004)$. In such a framework it would be possible to re-design courses in a professional association and hence combine the skills development of teachers with innovative strategies for curriculum development in schools (Engestrøm 2004, p 12). Whether or not the transfer of training or further education into the everyday life of teachers succeeds largely depends on individual factors (Hoekstra et al., 2009). An open mind towards new ideas and the willingness to adopt and implement innovative proposals is the prerequisite for initiating and implementing change processes in school routine. How teachers learn informally differs from one individual to the next (Hoekstra et al., 2009). This aspect should be borne in mind when developing further education concepts and should lead to a sense of openness with respect to the curriculum, so that it is possible to adapt learning processes to the individual needs. One significant added value provided by the required openness is the ability to obtain feedback on the learning progress. For example, Zwart et al. (2008) suggest providing teachers with a "peer coach", who can help them reflect upon what has been learned (Hoekstra et al., 2009).

Moderating the reflection processes regarding teaching practice. Critical, individual reflection upon one's own teaching basically represents a central impetus for the skills development of teachers (Meirink et al., 2009). A change in thought structures and hence upskilling is possible especially when the teacher experiences cognitive dissonance, i.e. inconsistencies between their own perception and how they actually experience critical teaching phases (Lipowsky, 2011, p. 410). This raises the question as to what extent such learning options can be promoted in order to initiate appropriate reflection processes. The findings of the group led by Zwart et al. (2008, p 990) show that informal talks with students from the perspective of an observer offer a valuable learning option. Other examples involve mentoring programmes in which students act as trained mentors and assist the teacher in teaching with notebooks. "Reverse mentoring" is currently enjoying growing popularity even in business. Trainees who are familiar with and able to use digital media critically act as mentors for senior managers and help them find their way in the new digital world. It remains to be seen whether this is merely a short-term fad, or whether it will become established as an element of a changing learning and management culture. Reverse mentoring could also be an approach for the school learning environment to compensate for any lack of media skills on the part of teachers by using the potential of the digital natives. In this way the students' resources could contribute to the informal skills development of the teachers.

Furthermore, other forms of mentoring, such as near-peer shadowing, are capable of triggering reflection processes among teachers and thereby promoting the informal skills development (Meirink et al., 2009) Experimenting with new teaching methods (whether adapting a theoretically recognised concept, copying a colleague's method or developing one's own new idea) and even the immediate feedback from a colleague contributes substantially to the informal learning of teachers (Hoekstra et al. 2009; Meirink et al. 2009, p 90). In this regard, mentoring programmes can be orchestrated in different ways, i.e. the proportion of informal and formal elements of the learning process vary greatly (Colley, Hodkinson, \& Malcolm, 2003). The degree of refinement of the framework, such as the concrete learning setting, the place of learning or the general process, influences the "predictability of chance" in the further education for teachers and generates an added value for the school organisation and the learners.

Self-initiated learning in communities of practice. The idea of the near-peer mentoring entails a practice-oriented community of people (community of practice according to Wenger (1998), who are informally linked with each other, are faced with similar tasks, and shape the practice in this community through a self-organised exchange. "Professional Learning Communities" in the teaching profession have long been a popular research field (Hord, 1997; 
Stoll, Bolam, McMahon, Wallace, \& Thomas, 2006), but the effects of professional learning communities have yet to be researched in detail (Lipowsky, 2011, p. 408). The basic consensus in the literature seems to be that community-internal characteristics - such as high motivation for self-development and student focus - are required in order to address a deeper level of reflection in teachers as compared to a conventional training seminar (Lipowsky, 2011, p. 408). The literature on collegial reflection illustrates the added value of such working relations (Hoekstra et al., 2009; Meirink et al., 2009). Communities of practice increase the circle of possibilities for reflection and, provided the aforementioned conducive group characteristics exist, are another instrument of informal skills development of teachers. A beneficial environment for the successful interplay within the community of practice, such as the time window for the professional exchange, must be provided by the school.

Not only networking internally within the teaching staff, but also the search for forms of more intensive cooperation between learning locations, is a field that is still relatively young in Switzerland and has yet to be implemented systematically (Dubs, 2003). Schneider \& Mahs, (2003) provide one example of a concept of continuous self-qualification and cooperative self-organisation for the skills development of teams of trainers (trainers, teachers, professional services). Here, team meetings represent an important measure in the course of which training modules and further education per se can take place in a self-organised way through the multiplier principle (Schneider \& Mahs, 2003, p. 300). More recent examples support learning cooperation using Web 2.0 to bridge the gap between learning locations (Beiling, Fleck, \& Schmid, 2012). However, experience with knowledge forums (Kremer, 2003, p. 416) reveals that work within the forum has so far encountered considerable problems; there is often a lack of motivation to cooperate at the various locations. The formation of networks in relation to the outside world thus also has a bearing on the internal relationship between the participating organisations, ("which is why knowledge forums cannot become bridges between the organisations, yet bridges are built without ensuring the access," (Kremer, 2003, p. 416). Even when using Web 2.0 applications, the relevant prerequisites for success are therefore not so much technological as cultural factors that represent incentives for participation in the community of practice. The above-mentioned promotion of a climate that is conducive to cooperation within the school influences the informal learning activities of the teachers (Heise, 2009). The availability of time and virtual and real rooms fosters proactive action by the practical community (Overwien, 2009).

Based on the above examples, it is clear that the combination of formal and informal learning is possible in particular using two different approaches. "This can be done independently by the learner (e.g. through documentation, checklists, learning diary) and/or with support (e.g. learning process support, group discussions). By means of constructive and critical reflection on one's own experiences, the mere "gaining of experience becomes an effective learning experience that supports one's own skills development" (Rohs, 2007, p. 77). Alternatively, however, significance is attached to the structuring of the self-organisation of learning processes on the continuum between formal and informal. With this approach, self-organised learning is promoted in daily school routine through staffing, methodological or medial structuring aids. This makes it possible to tap experience of organised forms of learning gained in the course of everyday teaching practices for the acquisition of skills (for example through the parallelisation of project and learning tasks or observational tasks to focus the attention of the students). 


\section{Conclusion and future Trends: Systematic competence development: creation of basic conditions for learning opportunities}

The skills development of teachers, in particular in order to test and learn new teaching concepts, is inextricably linked to curriculum and school development. As already stated in the introduction, school routine is currently dominated by more traditional forms of teaching, in which innovative educational approaches are almost impossible to realise. "Such teaching practices are therefore the central impediment to the integration of e-learning in everyday school life" (Wilbers, 2012, p. 38).

The skills development of teachers for vocational training in the competent use of digital media therefore requires considerable efforts in the schools. Consequently, it is doubtless not enough to organise a new blended learning course as a further education offer for teachers, which is usually held as a one-time event. Hence the new further education course will continue to be out of place in the school. On the contrary, it appears all the more important that support initiatives for the skills development of teachers are based on this context and are simultaneously embedded in innovation strategies and quality development processes in schools (Schneider \& Mahs, 2003; Seufert, Lehner, \& Tödtli, 2013). As a result, curriculum development, staff training and school development measures must be coordinated in order to implement education reforms (Stoll et al., 2006). The development of a school culture in which students and teachers alike attach great importance to learning together and from each other is of central importance (Hord, 1997; Stoll et al., 2006). In this context, based on the learning organisation by Senge (1996), Hord (1997, p. 1) stresses the importance of community building for continuous learning ("communities of inquiry and improvement", p 120.) In the context of a comprehensive literature review, Hord (ibid.) identified in particular the following five success factors for promoting conditions conducive to learning in a school: 1) supportive and participative management, 2) shared vision and values, 3) collective creativity, 4) shared, personal practice, 5) supportive conditions that determine when, who and how the teachers meet regularly as a unit in order to initiate learning processes, take decisions, solve problems and work creatively, which is ultimately what characterises a professional learning community.

For a sustainable integration of digital media in a vocational school-system it needs besides a digital competences development program - in teams or individual, in informal or formal settings (Micro-level and Meso-level) - also a comprehensive school development and a framework for digital learning infrastructures. Figure 2 illustrate that both school development and digital competences programs should be mutually supportive. The usage of digital media in vocational schools has a strong disruptive effect: students bring their own devices in schools. It is natural for them to use it as instrument for learning, working and living. Schools and their teachers are not prepared yet for the necessary radical change in acquiring knowledge and bridging the gap between schools and the working environments in companies. Radical changes are needed to think over existing practice in teacher education at the school workplace. Therefore, the future perspective should focus on school and curriculum development supporting teachers as a professional learning community:

Insert Figure 2 here

Developing a learning-conducive school culture can be regarded today as one of the key challenges for the successful implementation of educational innovation and continuous quality improvement processes. To enable technology to become firmly established as a method and subject in school routine in the long term, appropriate framework conditions are required at the organisational level. At the macro level, schools must create conditions that allow learning 
with digital media. On the one hand, this involves providing the technological infrastructure, and on the other, rooms in which the personal training (both formal and informal) of teachers is possible. In this context, an appropriate learning culture must be established, which promotes learning with and from each other as well as the testing of new forms of teaching with digital media. According to Kerres \& Heinen (2012, p. 28), in addition to the creation of "digital learning infrastructures", a shared vision and accompanying internal communication structures need to be established by the stakeholders, with the school management playing a pioneering and leading role.

At the same time, learning takes place not only in the school context, but also at home, in the workplace, or in interaction with peers. Following Blömeke (2005), teachers who have school development skills, contribute to the development of institutional digital conditions and educate students and parents in digital media education terms. 


\section{References}

Beiling, B., Fleck, A., \& Schmid, C. (2012). Lernortkooperation mit dem Web 2.0 - ein neues Mittel für eine alte Herausforderung? Berufsbildung in Wissenschaft und Praxis (BWP), 3(41), 14-17.

Blömeke, S. (2000). Medienpädagogische Kompetenz: Theoretische und empirische Fundierung eines zentralen Elements der Lehrerausbildung. München: kopaed.

Blömeke, S. (2005). Medienpädagogische Kompetenz. In A. Frey, R. S. Jäger, \& U. Renold (Eds.), Berufspädagogik: Bd. 5. Kompetenzdiagnostik. Theorien und Methoden zur Erfassung und Bewertung von beruflichen Kompetenzen (pp. 76-97). Landau: Empirische Pädagogik e.V.

Colley, H., Hodkinson, P., \& Malcolm, J. (2003). Formality and Informality in Learning. London: Learning and Skill Research Centre.

Dubs, R. (2003). Schweiz. In D. Euler (Ed.), Handbuch der Lernortkooperation. Band 1: theoretische Fundierungen (pp. 564-579). Bielefeld: Bertelsmann.

Engestrøm, Y. (2004). New forms of learning in co-configuration work. Journal of Workplace Learning, $16(1 / 2), 11-21$.

Euler, D. (2012). Wie wir unterrichten sollten. Folio, (3), 21.

Euler, D., \& Hahn, A. (2004). Wirtschaftsdidaktik. Bern: Haupt Verlag.

Euler, D., \& Hahn, A. (2014). Wirtschaftsdidaktik: $r$ (3., aktual. Aufl.). Bern, Bern: UTB; Haupt Verlag.

Euler, D., Hasanbegovic, J., Kerres, M., \& Seufert, S. (2006). Handbuch der Kompetenzentwicklung für E-Learning Innovationen: Eine Handlungsorientierung für innovative Bildungsarbeit in der Hochschule (1. Aufl.). Aus dem Programm Huber. Psychologie-Praxis. Reihe Lernen mit neuen Medien. Bern: Huber.

Heise, M. (2007). Professionelles Lernen jenseits von Fortbildungsmaßnahmen. Zeitschrift für Erziehungswissenschaft, 10(4), 513-531.

Heise, M. (2009). Informelles Lernen bei Lehrkräften. In M. Bodowski, U. Devers-Kanoglu, B. Overwien, M. Rohs, S. Salinger, \& M. Walser (Eds.), Informelles Lernen und Bildung für eine nachhaltige Entwicklung. Beiträge aus Theorie und Praxis (pp. 255-264). Leverkusen/Opladen: Budrich.

Herzig, B., \& Grafe, S. (2009). Digitale Medien in Schule und Alltagswelt: Zur Verbindung von formalen und informellen Lernprozessen. In B. Bachmair (Ed.), Medienbildung in neuen Kulturräumen (pp. 183-195). Wiesbaden: VS Verlag für Sozialwissenschaften.

Hoekstra, A., Korthagen, F., Brekelmans, M., Beijaard, D., \& Immants, J. (2009). xperienced teachers' informal workplace learning and perceptions of workplace conditions. Journal of Workplace Learning, 21(4), 276298.

Hord, S. M. (1997). Professional learning communities: Communities of continuous inquiry and improvement. Austin, Texas: Southwest Educational Development Laboratory.

Jurasaite-Harbison, E. (2009). Teachers' workplace learning within informal contexts of school cultures in the United States and Lithuania. Journal of Workplace Learning, 21(4), 299-321.

Kerres, M., Euler, D., Seufert, S., Hasanbegovic, J., \& Voss, B. (2005). Lehrkompetenz für eLearning-Innovationen in der Hochschule: Ergebnisse einer explorativen Studie zu Maßnahmen der Entwicklung von eLehrkompetenz (SCIL Arbeitsbericht No. 6). St. Gallen.

Kerres, M., \& Heinen, R. (2012). Schulentwicklung und digitale Lerninfrastruktur: Perspektiven und Handlungsfelder. schulmanagement, (3), 26-28.

Koehler, M. J., \& Mishara, P. (2009). What is technological pedagogical content knowledge? Contemporary Issues in Technology and Teacher Education, 9(1), 60-70.

Kremer, H. (2003). Wissensforum als Instrument der Lernortkooperation. In D. Euler (Ed.), Handbuch der Lernortkooperation. Band 2: Praktische Erfahrungen (pp. 411-418). Bielefeld: Bertelsmann.

Lipowsky, F. (2011). Theoretische Perspektiven und empirische Befunde zur Wirksamkeit von Lehrerfort- und weiterbildung. In E. Terhart, H. Bennewitz, \& M. Rothland (Eds.), Handbuch der Forschung zum Lehrerberuf (pp. 398-417). Münster/New York/München/Berlin: Waxmann.

Ludwig, L., Narr, K., \& Frank, S. (2013). Abschlussbericht Initiative "Lernen in der digitalen Gesellschaft - offen, vernetzt, integrativ. Internet \& Gesellschaft Co:llaboratory,

Mayrberger, K. (2007). Verändertes Lernen mit neuen Medien? : Strukturanalyse gemeinschaftlicher Interaktion in einer computergestützten Lernumgebung in der Grundschule. Hamburg: Verlag Dr. Kovac. 
Mayrberger, K. (2012). Medienpädagogische Kompetenz im Wandel - Vorschlag zur Gestaltung des Übergangs in der Lehrerbildung am Beispiel mediendidaktischer Kompetenz. In R. Schulz-Zander (Ed.), Jahrbuch Medienpädagogik: Bd. 9 (2012). Jahrbuch Medienpädagogik 9 (pp. 389-412). Wiesbaden: Springer VS.

Meirink, J., Meijer, P., Verloop, N., \& Bergen, T. (2009). How do teachers learn in the workplace?: An examination of teacher learning activities. European Journal of Teacher Education, 32(3), 209-224.

Overwien, B. (2009). Schulorte und Raumgefüge informellen Lernens. In J. Böhme (Ed.), Schularchitektur im interdisziplinären Diskurs. Territorialisierungskrise und Gestaltungsperspektiven des schulischen Bildungsraums. Wiesbaden.

Petko, D., \& Döbeli Honegger, B. (2011). Digitale Medien in der schweizerischen Lehrerinnen- und Lehrerbildung: Hintergründe, Ansätze und Perspektiven. Beiträge zur Lehrerbildung, 29(2).

Richardson, V. (2003). The dilemmas of Professional Development. Phi Delta Kappan, 85(5), 401-411.

Rohs, M. (2007). Zur Theorie formellen und informellen Lernens in der IT-Weiterbildung. Universität der Bundeswehr Hamburg, Hamburg. Retrieved from https://www.deutsche-digitale-bibliothek.de/binary/MV7JDGZH33VAWF6S5DLYV3JCETEVKDFK/full/1.pdf

Schneider, P., \& Mahs, C. (2003). Kontinuierliche und Kooperative Selbstqualifikation und Selbstorganisation (KoKoSS) der Ausbilder. In D. Euler (Ed.), Handbuch der Lernortkooperation. Band 2: Praktische Erfahrungen (pp. 298-312). Bielefeld: Bertelsmann.

Senge, P. M. (1996). Die fünfte Disziplin: Kunst und Praxis der lernenden Organisation. Stuttgart: Klett-Cotta.

Seufert, S. (2012). Die digitale Revolution und die Evolution des Lehrens. Folio, (4), 36-38.

Seufert, S. (2013). Bildungsmanagement: Einführung für Studium und Praxis. Stuttgart: Schäffer-Poeschel.

Seufert, S., Lehner, M., \& Tödtli, M. (2013). Didaktisierung des Informellen Lernens. In S. Seufert \& C. Metzger (Eds.), Kompetenzentwicklung in unterschiedlichen Lernkulturen. Festschrift für Dieter Euler zum 60. Geburtstag (pp. 487-507). Paderborn: Eusl.

Seufert, S. \& Scheffler, N. (2014). Medienkompetenzen in der Berufsbildung: Theoretische Grundlagen und empirische Erhebung bei Auszubildenden der Schindler AG (Arbeitsbericht Institut für Wirtschaftspädagogik). St. Gallen.

Shulman, L. (1986). Those who understand: Knowledge growth in teaching. Educational Researcher, 15(2), 4 14.

Shulman, L. (1987). Knowledge and teaching: Foundations of the new reform. Harvard Educational Review, 57(1), 1-22.

Sloane, P. (2002). Schulorganisation und schulische Curriculumarbeit. In R. Bader \& P. Sloane (Eds.), Bildungsmanagement im Lernfeldkonzept. Curriculare und organisatorische Gestaltung. Beiträge aus den Modellverbünden NELE \& SELUBA (pp. 9-25). Paderborn: Eusl.

Spanhel, D. (2009). Bildung in der Mediengesellschaft: Medienbildung als Grundbegriff der Medienpädagogik. In B. Bachmair (Ed.), Medienbildung in neuen Kulturräumen (pp. 45-58). Wiesbaden: VS Verlag für Sozialwissenschaften.

Stanoevska-Slabeva, K., Müller, S., Seufert, S., \& Scheffler, N. (Eds.) (2015a). „The 7i Framework - Towards a Measurement Model for Information Literacy." Proceedings of the American Conference on Information Systems (AMCIS),. Fajardo, PR.

Stanoevska-Slabeva, K., Müller, S., Seufert, S., \& Scheffler, N. (2015b). Modelling and Measuring Information Literacy in Secondary Education. International Conference on Information Systems (ICIS). Fort Worth, Texas.

Stoll, L., Bolam, R., McMahon, A., Wallace, M., \& Thomas, S. (2006). Professional Learning Communities: A Review of the Literature. Journal of Educational Change, 7, 221-258.

Weiss, R. (2012). Medienkompetenz als neue Kulturtechnik. Berufsbildung in Wissenschaft und Praxis (BWP), $41(3), 3$.

Wenger, E. (1998). Communities of Practice. Learning, Meaning, and Identity. Cambridge University, Cambridge.

Wilbers, K. (2012). Entwicklung der Kompetenzen von Lehrkräften berufsbildender Schulen für digitale Medien. Berufsbildung in Wissenschaft und Praxis (BWP), (3), 38-41.

Zwart, R., Wubbels, T., Bolhuis, S., \& Bergen, T. (2008). Teacher learning through reciprocal peer coaching: An analysis of activity sequences. Teaching and Teacher Education, 24(4), 982-1002. 


\section{Figures}

Figure 1. The integration of digital media to foster teacher's competences using the example of the TPACKmodel.

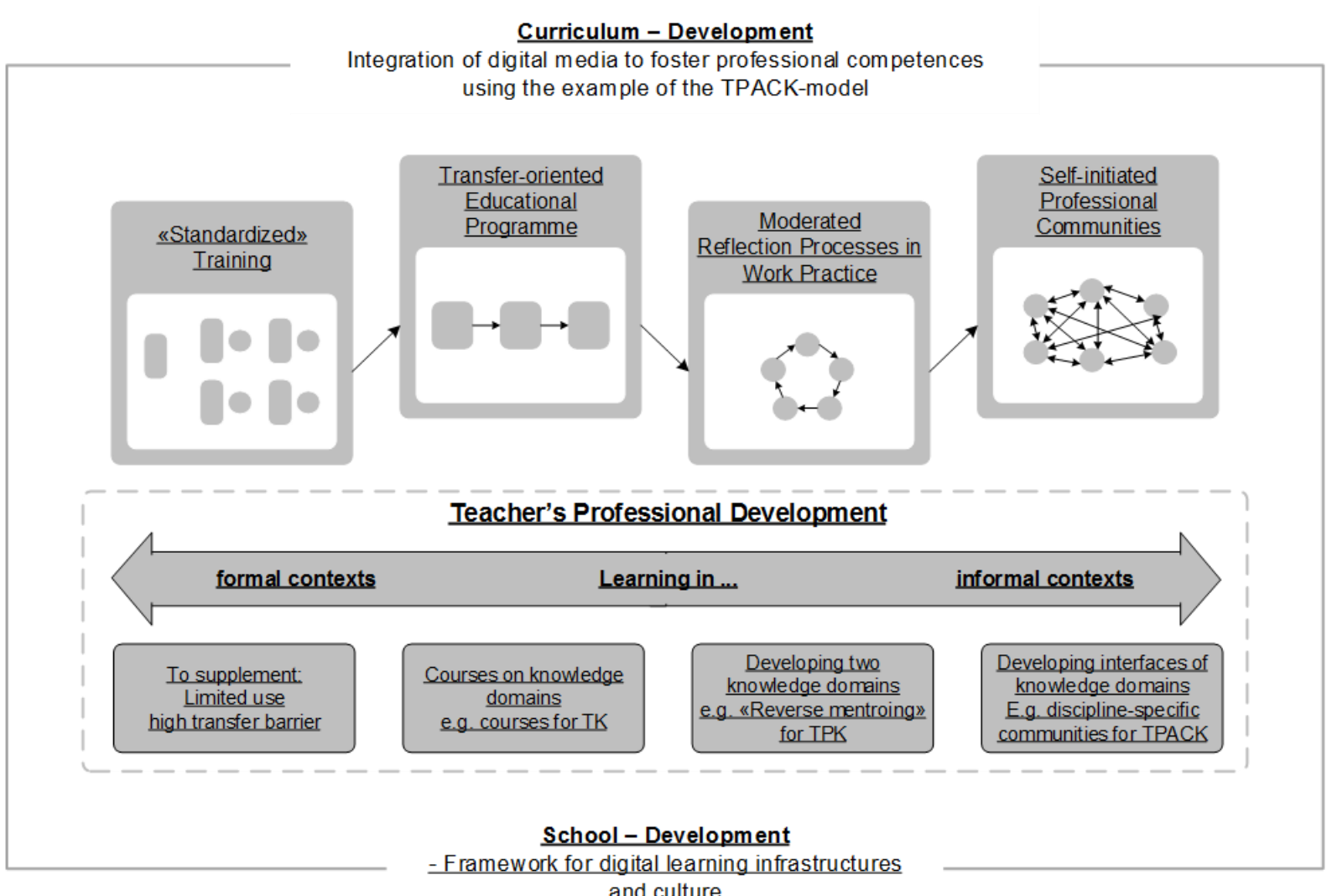
and culture

Figure 2. Connection between skill, school and programme development. (Seufert, 2013, p. 294).

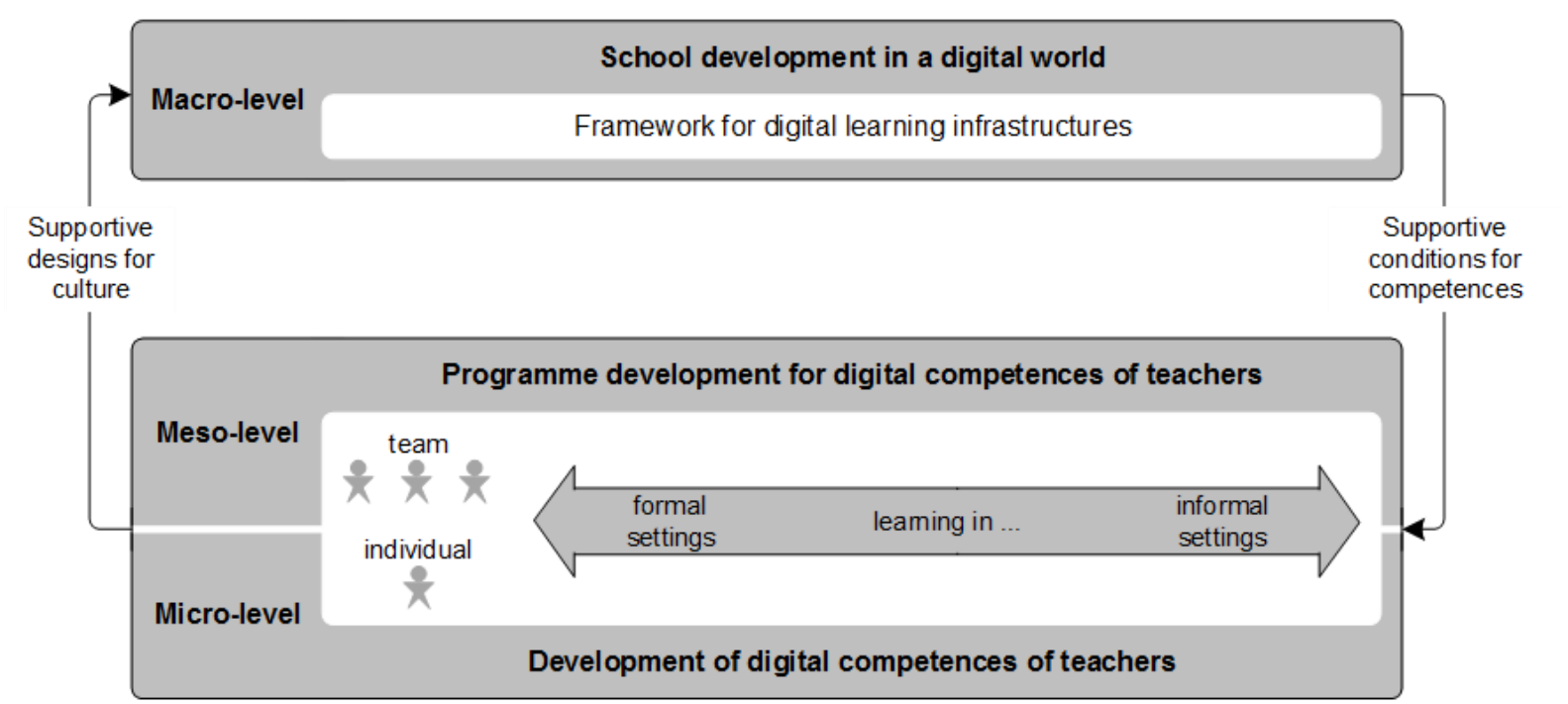

